\title{
29. CONSOLIDATION AND PERMEABILITY CHARACTERISTICS OF JAPAN TRENCH AND NANKAI TROUGH SEDIMENTS FROM DEEP SEA DRILLING PROJECT LEG 87, SITES 582, 583, AND 5841
}

\author{
Mark W. Johns, Department of Oceanography, Texas A\&M University²
}

\begin{abstract}
The results of nine consolidation and permeability tests are presented for sediment samples from the Japan Trench and Nankai Trough sites of Leg 87. Coring and degassing disturbance results in an underconsolidated state for most Site 582 samples; however, the compressional effects of the subduction zone and high sediment accumulation rates may also play a role in causing underconsolidation. Samples collected at Site 583 exhibit similar evidence of disturbance but are slightly overconsolidated, confirming the possibility of sediment erosion at this site. The highly diatomaceous sediments at Site 584 are all overconsolidated, but the trend of overconsolidation decreases with depth. Disturbances of the diatom clay structure may increase the sediment compressibility and create this apparent overconsolidation.
\end{abstract}

\section{INTRODUCTION}

Consolidation characteristics of marine sediments from the Japan Trench and Nankai Trough regions (Trabant et al., 1975; Shephard and Bryant, 1977) and geotechnical investigations of the slope development of various trench systems (Lee et al., 1973; Carson et al., 1974; Trabant et al., 1975; Shephard and Bryant, 1977; Taylor and Bryant, in press) are used to evaluate sedimentary processes and the relationship between subduction and accretion.

Lee and others (1973) tested sediments collected from below $300 \mathrm{~m}$ sub-bottom at DSDP Site 181 in the Aleutian Trench and found them to be overconsolidated. Highly overconsolidated sediments occur below $397 \mathrm{~m}$ at DSDP Site 298 in the Nankai Trough (Trabant et al., 1975) and in mudstones dredged from the Cascadia Basin (Carson, 1977). In contrast, sediments are highly underconsolidated from the seafloor down to $593 \mathrm{~m}$ sub-bottom in the Japan Trench at Sites 436, 438, and 440 (Shephard and Bryant, 1977) and are underconsolidated in sediments from terraces of the Middle America slope (Taylor and Bryant, in press). Faas (1982a, b) reports that the physical properties of Leg 67 sediments (Guatemalan margin) are dominated by in situ gas and downslope sediment transport.

Overconsolidated sediments may result from tectonically induced stresses, deformation, and/or uplift (Lee et al., 1973; Trabant et al., 1975; Carson, 1977). The underconsolidation of sediments from the Middle America Trench sites is attributed to high internal porewater pressures and the presence of gas and gas hydrates (Taylor and Bryant, in press). A rigid framework developed by particle-to-particle interaction between diatoms and clays may cause the underconsolidation displayed by the Japan Trench samples (Shephard and Bryant, 1977).

The following discussion describes the consolidation and permeability test results from samples obtained in

\footnotetext{
${ }^{1}$ Kagami, H., Karig, D. E., Coulbourn, W. T., et al., Init. Repts. DSDP, 87: Washington (U.S. Govt. Printing Office)

2 Present address: P.O. Box 3817, College Station, Texas 77844.
}

the Japan Trench and Nankai Trough regions during Leg 87 for sub-bottom depths less than $185 \mathrm{~m}$.

\section{METHODS}

Nine consolidation and permeability tests were performed using Anteus back-pressure consolidometers modified for falling head permeability measurements on whole round core samples from Sites 582, 583, and 584 (Table 1). A description of the general techniques for consolidation testing and advantages of back-pressure consolidometers can be found in Lambe (1951), Lowe and others (1964), Lambe and Whitman (1969), and Bowles (1970).

The state of consolidation for a particular sample is determined by comparing the effective preconsolidation stress, $\sigma_{\mathrm{p}}^{\prime}$, calculated using the Casagrande technique (1936), to the effective overburden stress, $\sigma_{\mathrm{vo}}^{\prime}$, calculated with the assumption of no excess hydrostatic pressure. For normally consolidated sediments, the present effective overburden stress is the maximum ever imposed, therefore $\sigma_{\mathrm{p}}^{\prime}$ equals $\sigma_{\mathrm{vo}}^{\prime}$. Overconsolidated sediments were consolidated under a stress in excess of the present effective overburden stress, meaning that $\sigma_{\mathrm{p}}^{\prime}$ is greater than $\sigma_{\mathrm{vo}}^{\prime}$. The underconsolidated state implies that the sediments have not fully consolidated under the present effective overburden stress; hence, $\sigma_{\mathrm{p}}^{\prime}$ is less than $\sigma_{\mathrm{vo}}^{\prime}$.

The overconsolidation ratio (OCR) is the ratio of $\sigma_{\mathrm{p}}^{\prime}$ to $\sigma_{\mathrm{vo}}^{\prime}$ and represents the state of consolidation numerically. An OCR equal to 1 represents a normally consolidated sediment, whereas an OCR greater than 1 shows overconsolidation and an OCR less than 1 shows underconsolidation. Permeability values at the effective preconsolidation stress, $\kappa_{c}$, are interpolated estimates of the falling head permeability values corresponding to the void ratio at the effective preconsolidation stress, $e_{c}$ (Table 1). Permeabilities and void ratios estimated in this manner are likely to approach the in situ values of the sediments.

Shore-based laboratory measurements of physical properties were made and include water content, Atterberg limits, wet-bulk density, specific gravity, grain size, calcium carbonate (wt.\%), and shear strength from samples taken for consolidation testing (Table 2). An air comparison pycnometer with helium as the gas medium was used for volumetric determinations (Table 2). Vane shear measurements were made using a motorized vane at a shear rate of $60^{\circ}$ per minute ( 1.05 radians per minute). Calcium carbonate (wt. \%) was determined using the Schiebler technique (Bouma, 1969). Grain-size analysis was performed using the pipette method for silts and clays (Folk, 1974).

\section{CONSOLIDATION CHARACTERISTICS}

\section{Nankai Trough}

\section{Site 582 (Holes 582 and 582B)}

Site 582 is located on the floor of the Nankai Trough approximately $1 \mathrm{~km}$ seaward of the toe of the thrust 
Table 1. Consolidation characteristics for Sites 582, 583, and 584.

\begin{tabular}{|c|c|c|c|c|c|c|}
\hline $\begin{array}{l}\text { Hole-Core-Section } \\
\text { (interval in } \mathrm{cm} \text { ) }\end{array}$ & $\begin{array}{l}\text { Depth } \\
\text { sub-bottom } \\
\text { (m) }\end{array}$ & $\begin{array}{c}\text { Effective } \\
\text { overburden } \\
\text { stress } \\
\sigma_{\text {vo }}^{\prime}(\mathrm{kPa})\end{array}$ & $\begin{array}{c}\text { Effective } \\
\text { preconsolidation } \\
\text { stress } \\
\sigma_{\mathrm{p}}^{\prime}(\mathrm{kPa})\end{array}$ & $\begin{array}{l}\text { Over- } \\
\text { consolidation } \\
\text { ratio } \\
\text { (OCR) }\end{array}$ & $\begin{array}{l}\text { Void ratio } \\
\text { at } \sigma_{\mathrm{p}}^{\prime} \\
\left(\mathrm{e}_{\mathrm{c}}\right)\end{array}$ & $\begin{array}{l}\text { Permeability } \\
\text { at } \sigma_{\mathrm{p}}^{\prime} \\
\left(\kappa_{\mathrm{c}} \text { in } \mathrm{cm} / \mathrm{s}\right)\end{array}$ \\
\hline $582-1-6,144-147$ & 8.90 & 59 & 220 & 3.73 & 1.182 & $1.40 \times 10^{-6}$ \\
\hline $582 \mathrm{~B}-3-3,144-147$ & 72.34 & 563 & 85 & 0.15 & 0.990 & $4.17 \times 10^{-}$ \\
\hline $582 \mathrm{~B}-8-3,69-72$ & 119.79 & 963 & 220 & 0.23 & 1.066 & $6.55 \times 10^{-7}$ \\
\hline $582 \mathrm{~B}-14-7,35-38$ & 183.35 & 1494 & 50 & 0.03 & 0.792 & $1.38 \times 10^{-6}$ \\
\hline $583 \mathrm{~B}-5-2,136-139$ & 22.36 & 164 & 210 & 1.28 & 1.019 & $4.74 \times 10^{-6}$ \\
\hline $583 \mathrm{~A}-5-3,127-130$ & 23.27 & 156 & 190 & 1.21 & 0.945 & $1.32 \times 10^{-6}$ \\
\hline $584-4-6,112-115$ & 38.02 & 155 & 305 & 1.97 & 2.475 & $3.79 \times 10^{-6}$ \\
\hline $584-5-6,142-145$ & 47.72 & 188 & 310 & 1.65 & 2.685 & $4.56 \times 10^{-6}$ \\
\hline $584-8-1,113-116$ & 68.53 & 264 & 310 & 1.17 & 2.610 & $5.52 \times 10^{-6}$ \\
\hline
\end{tabular}

Table 2. Physical properties data for Sites 582, 583, and 584.

\begin{tabular}{|c|c|c|c|c|c|c|c|c|c|c|c|c|}
\hline \multirow[b]{2}{*}{$\begin{array}{l}\text { Hole-Core-Section } \\
\text { (interval in } \mathrm{cm} \text { ) }\end{array}$} & \multirow[b]{2}{*}{$\begin{array}{c}\text { Depth } \\
\text { sub-bottom } \\
\text { (m) }\end{array}$} & \multirow{2}{*}{$\begin{array}{l}\text { Initial } \\
\text { water } \\
\text { content } \\
(\%)\end{array}$} & \multirow[b]{2}{*}{$\begin{array}{l}\text { Initial } \\
\text { void } \\
\text { ratio }\end{array}$} & \multirow[b]{2}{*}{$\begin{array}{l}\text { Porosity } \\
(\%)\end{array}$} & \multirow[b]{2}{*}{$\begin{array}{c}\text { Bulk } \\
\text { density } \\
\left(\mathrm{Mg} / \mathrm{m}^{3}\right)\end{array}$} & \multirow[b]{2}{*}{$\begin{array}{l}\text { Specific } \\
\text { gravity }\end{array}$} & \multicolumn{3}{|c|}{ Grain size } & \multicolumn{2}{|c|}{ Atterberg limits } & \multirow[b]{2}{*}{$\begin{array}{c}\text { Calcium } \\
\text { carbonate } \\
\text { (wt. \%) }\end{array}$} \\
\hline & & & & & & & $\begin{array}{l}\text { Sand } \\
(\%)\end{array}$ & $\begin{array}{l}\text { Silt } \\
(\%)\end{array}$ & $\begin{array}{l}\text { Clay } \\
(\%)\end{array}$ & $\begin{array}{l}\text { Liquid } \\
\text { limit } \\
(\%)^{*}\end{array}$ & $\begin{array}{l}\text { Plastic } \\
\text { limit } \\
(\%)\end{array}$ & \\
\hline $582-1-6,144-147$ & 8.90 & 91 & 2.459 & 69.8 & 1.531 & 2.73 & 1.42 & 65.41 & 33.18 & & & 1.10 \\
\hline $582 \mathrm{~B}-3-3,144-147$ & 72.34 & 41 & 1.179 & 53.1 & 1.813 & 2.72 & 0.60 & 78.28 & 21.12 & 52 & 37 & 0.11 \\
\hline $582 \mathrm{~B}-8-3,69-72$ & 119.79 & 46 & 1.243 & 55.5 & 1.789 & 2.68 & 0.27 & 58.48 & 41.26 & 55 & 44 & 1.69 \\
\hline $582 \mathrm{~B}-14-7,35-38$ & 183.35 & 32 & 0.906 & 44.7 & 1.947 & 2.70 & 0.79 & 71.69 & 27.51 & 46 & 30 & 0.70 \\
\hline 583B-5-2, 136-139 & 22.36 & 45 & 1.196 & 53.7 & 1.799 & 2.69 & 0.38 & 58.11 & 41.51 & 41 & 38 & 0.04 \\
\hline $583 \mathrm{~A}-5-3,127-130$ & 23.27 & 44 & 1.154 & 45.4 & 1.929 & 2.70 & 10.00 & 89.97 & 0.03 & 66 & 40 & 0.20 \\
\hline $584-4-6,112-115$ & 38.02 & 113 & 2.880 & 75.6 & 1.360 & 2.31 & 2.19 & 53.20 & 44.61 & 143 & 106 & 0 \\
\hline $584-5-6,142-145$ & 47.72 & 140 & 3.132 & 75.0 & 1.337 & 2.31 & 7.21 & 57.08 & 35.71 & 144 & 125 & 0 \\
\hline $584-8-1,113-116$ & 68.53 & 134 & 3.199 & 75.8 & 1.347 & 2.39 & 4.74 & 64.16 & 31.10 & 161 & 89 & 0 \\
\hline
\end{tabular}

drilled at Site 583 and represents trench-fill sediments. Dark olive gray silty clays from $8.90 \mathrm{~m}, 72.34 \mathrm{~m}, 119.79$ $\mathrm{m}$, and $183.35 \mathrm{~m}$ sub-bottom were tested. Consolidation test results (Fig. 1), plotted as void ratio versus vertical effective stress (e versus $\log \sigma_{v}^{\prime}$ ), show the near-surface sample $(8.90 \mathrm{~m})$ is overconsolidated, whereas the three deeper samples (below $72 \mathrm{~m}$ ) are underconsolidated.

These samples were collected by rotary coring methods and also exhibit considerable evidence of degassing disturbance. Samples 582-1-6, 144-147 cm (Fig. 1A) and 582B-8-3, 69-72 cm (Fig. 1B) show gradual slope changes to the virgin curve, whereas Samples 582B-3-3, 144-147 cm (Fig. 1A) and 582B-14-7, 35-38 cm (Fig. 1B) exhibit more pronounced changes to the virgin curve, suggesting less disturbance for the latter samples.

\section{Site 583 (Holes 583A and 583B)}

Site 583 was drilled on the lowest structural terrace of the landward slope of the Nankai Trough. Consolidation tests were performed on Samples 583A-5-3, 127$130 \mathrm{~cm}$ and 583B-5-2, 136-139 cm, both collected by hydraulic piston corer. Hole $583 \mathrm{~A}$ was drilled $400 \mathrm{~m}$ farther landward than Hole 583 in an effort to sample the uppermost part of the section observed on the $3.5-\mathrm{kHz}$ profiles. Hole 583B constitutes part of a hole through the toe of the thrust. The sample from Hole 583B is a light olive gray silty clay deposited above and in contact with an ash layer. The Hole 583A sample is a dark olive gray silt. The results of the consolidation tests show these samples are slightly overconsolidated (Fig. 2). Visual inspection of the consolidation samples reveals some degassing disturbance, and the gradual change in slope in their consolidation curves substantiates sample disturbance. The gradual slope of the reload portion of the consolidation curve also makes evaluation of $\sigma_{\mathrm{p}}^{\prime}$ tentative.

\section{Japan Trench}

\section{Site 584}

Site 584 is situated on a deep-sea terrace of the Japan Trench slope about $42.5 \mathrm{~km}$ upslope from the trench axis. Consolidation tests were performed on highly diatomaceous sediments from $38.02 \mathrm{~m}, 47.72 \mathrm{~m}$, and $68.53 \mathrm{~m}$ sub-bottom. These olive green diatomaceous clayey silts are overconsolidated, and the degree of overconsolidation decreases with depth (Fig. 3). Although the samples did not exhibit disturbance because of degassing, the gradual change in slope from the reload portion of the consolidation curves to the virgin curves and the steeper slope of the initial reload curve compared with the unloading rebound curves do suggest sample disturbance.

\section{DISCUSSION}

During the process of gravitational compaction, the void ratio of a given sediment decreases by the addition of sedimentary overburden. In underconsolidated sediments, porewater pressures exceed hydrostatic or steady state because of factors that impede the flow of water through the sediment or induce stresses that contribute to the development of excess porewater pressures. These factors include (1) high sediment accumulation rates; (2) low permeabilities; (3) laterally applied stresses; and (4) physiochemical interparticle bonding and cementation. 

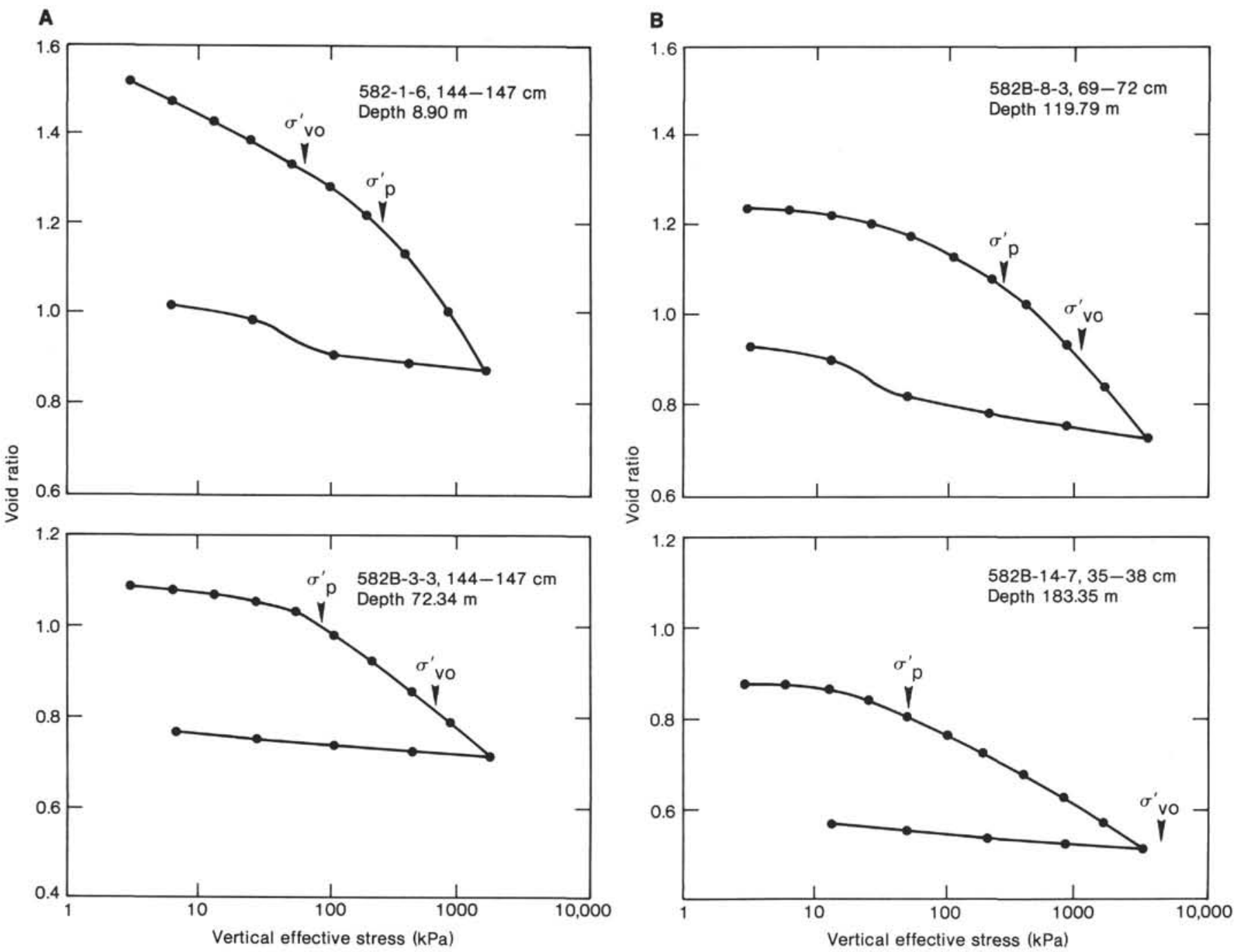

Figure 1. Site 582, void ratio versus logarithm of vertical effective stress (e versus $\log \sigma_{v}^{\prime}$ ) curves. Depths are sub-bottom depths. See text for a discussion of $\mathrm{A}$ and $\mathrm{B}$.

Overconsolidation, where pore pressure is less than hydrostatic pressure results from (1) cementation; (2) slow rates of sediment accumulation; (3) rapid drainage of interstitial water; and (4) erosion of overburden.

The results of the consolidation testing for the Nankai Trough region clearly delineate two environments. Site 582 was drilled in the floor of the Nankai Trough, whereas Site 583 was drilled slightly updip in the toe of the thrust across the lowest structural terrace.

Site 582 sediments exhibit near-surface overconsolidation ( $8.90 \mathrm{~m}$ sub-bottom) and become highly underconsolidated with depth ( 72 to $183 \mathrm{~m}$ sub-bottom) (Fig. 4). Near-surface sediments frequently show an apparent state of overconsolidation resulting from the internal strength of the sediments denoted as "origin cohesion" (Skempton, 1970; Bryant et al., 1981). Effective overburden stress is relatively low for Sample 582-1-6, 144-147 cm, yet the consolidation curve does indicate a change in slope to the virgin curve. The change in curvature of the initial loadings to the virgin curve is not distinct and may indeed indicate sample disturbance. In addition, values of water content and void ratio are high. Site 582 sedi- ments were particularly gassy in the upper $260 \mathrm{~m}$ (C. Bray, pers. comm., 1983).

The highly underconsolidated sediments of Site 582B (72 to $183 \mathrm{~m}$ sub-bottom) may result from a combination of events. The most likely cause of underconsolidated sediments at this site appears to be closely tied to its position in the Nankai Trough. Accumulation rates are quite high and variable, 206 to $340 \mathrm{~m} / \mathrm{Ma}$ for the uppermost $126 \mathrm{~m}$ and $866 \mathrm{~m} / \mathrm{Ma}$ for the deeper portion of Lithologic Unit 1 (see Sediment Accumulation Rates section, site chapter, Site 582, this volume). A combination of ridges, canyons, gullies, and catchments tend to trap sediments shed from Shikoku Island. Episodic deposition of axial turbidites in the vicinity of Site 582 would result in relatively rapid increases in overburden, producing excess porewater pressures in the underlying sediments.

Excess pore pressures may approach lithostatic pressures during rapid accumulation of sediments of low permeability. This relationship is theoretically demonstrated for sediments accumulating at rates of $500 \mathrm{~m} / \mathrm{Ma}$, assuming permeabilities of less than $1 \times 10^{-8} \mathrm{~cm} / \mathrm{s}$ (Bre- 


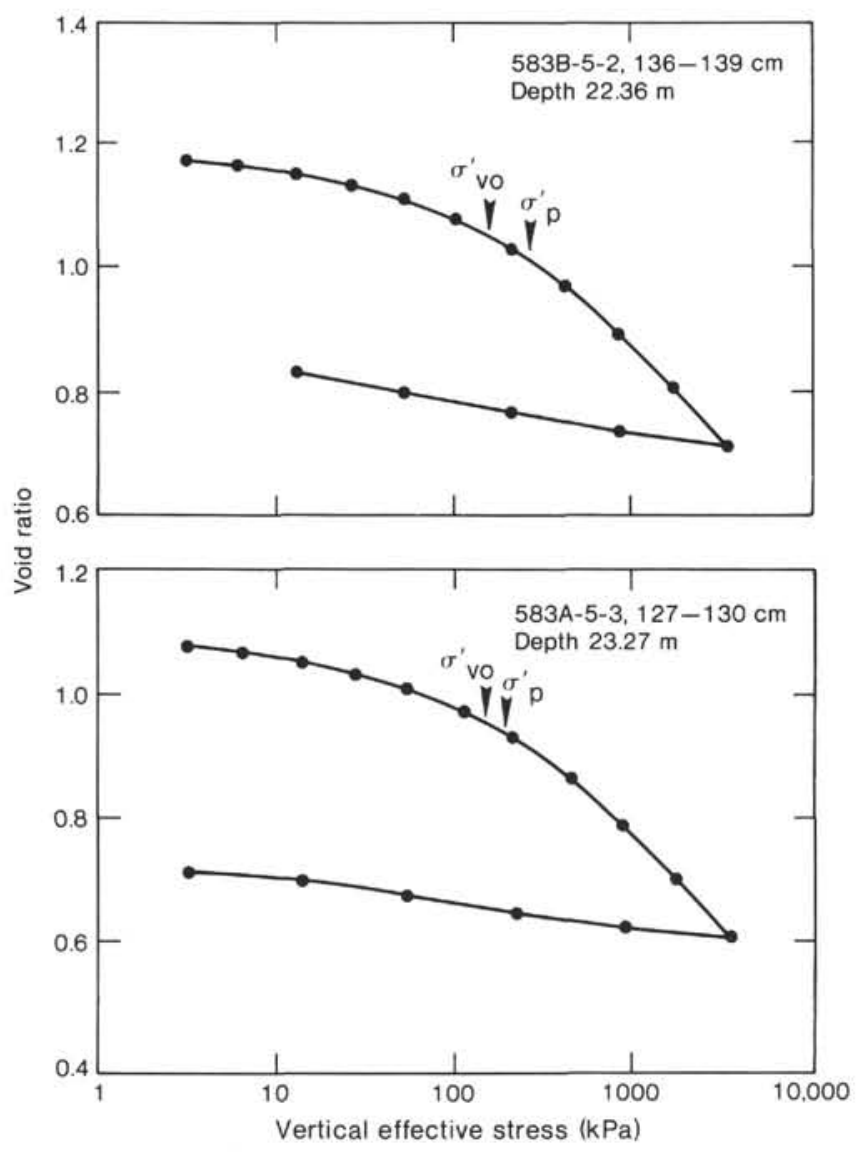

Figure 2. Site 583, void ratio versus logarithm of vertical effective stress (e versus $\log \sigma_{v}^{\prime}$ ) curves. Depths are sub-bottom depths.

dehoft and Hanshaw, 1968). The measured permeability values for Site 582 sediments range between $10^{-6}$ to $10^{-7}$ $\mathrm{cm} / \mathrm{s}$ depending on porosity (Fig. 5), and Sample 582B3-3 had much higher permeability values of $10^{-4}$ to $10^{-5}$ $\mathrm{cm} / \mathrm{s}$. Thus, the sedimentation rates appear to be of the proper magnitude to produce excess porewater pressures at depth. Yet, the sediment permeabilities appear to be sufficient to allow drainage of any excess porewater pressures.

Coring and degassing disturbance of the sediments of Site 582 contributed to the highly underconsolidated state of the deeper samples. However, the general character of the e versus $\log \sigma_{\mathrm{v}}^{\prime}$ curves for Samples 582B-3-3, $144-147 \mathrm{~cm}$ and 582B-14-7, 35-38 cm suggest minimal sample disturbance (Fig. 1). High sediment accumulation rates in conjunction with tectonically induced stresses appear to be sufficient to produce excess porewater pressures. Although sediment permeabilities are high, insufficient time may have elapsed to allow drainage of any excess porewater pressures developed in these Quaternary sediments.

The two consolidation test results for Site 583 sediments (Holes 583A and 583B) indicate that both samples are slightly overconsolidated, with OCR values of 1.2 to 1.3 . Both samples were collected by hydraulic piston coring methods and appear to be relatively undisturbed (Fig. 4). Both the general character of the change in slope to the virgin curve (Fig. 2) and the approxi- mately parallel relationship between the initial loading portion and the rebound portion of the e versus $\log \sigma_{\mathrm{v}}^{\prime}$ curves confirm the overall lack of disturbance.

Test results are in agreement with the hypothesis of sediment erosion at Site 583 (Leg 87 Scientific Party, 1983). The sediment permeabilities range between $10^{-5}$ and $10^{-7} \mathrm{~cm} / \mathrm{s}$ (Fig. 5).

The consolidation test results for Site 584, Japan Trench, differ from those reported for Sites 436, 438, and 440 (Shephard and Bryant, 1977). Sediments tested in this study are overconsolidated, and OCR values decrease with depth (Fig. 4). Sediment accumulation rates for this site ranged from 70 to $200 \mathrm{~m} / \mathrm{Ma}$, lower than those reported by Shephard and Bryant (1977); however, the permeabilities for Site 584 were in the range of $10^{-5}$ to $10^{-6} \mathrm{~cm} / \mathrm{s}$ (Fig. 5), an order of magnitude greater than those reported by Shephard and Bryant (1977). The samples tested for this study were collected from soft, lower Pliocene diatomaceous muds, nearer the trench axis than were Site 440 samples.

Shephard and Bryant (1977) suggested that the rigid framework of the diatom clay sediments collapses readily when "rapidly" loaded, as during the laboratory consolidation test, yet the structure is able to withstand in situ stresses imparted by lithostatic and tectonic forces. The diatomaceous sediments tested in this study were sampled from depths between 38 and $69 \mathrm{~m}$ sub-bottom. The gradual change in the slope of the reload portion of the consolidation curves shows that these near-surface diatomaceous sediments readily collapsed during laboratory testing. The character of the e versus $\log \sigma_{\mathrm{v}}^{\prime}$ curves indicate considerable sample rebound in the initial loading portions (Fig. 3). This behavior may be a result of sample disturbance, in which case the diatom skeletons may increase the sediment compressibility, thereby creating an apparent state of overconsolidation with continuous collapse of structure.

The Japan Trench and Nankai Trough sediments each have unique consolidation characteristics. Diatomaceous oozes of the Japan Trench region exhibit quite distinct variations with depth and increased overburden, apparently forming a rigid framework as overburden increases. Disturbance of this rigid framework apparently increases the compressibility of the sediments and alters the consolidation characteristics. The sediments of the Nankai Trough region have been modified by variable sedimentation rates, possibly causing underconsolidation, and in some cases mass wasting, creating overconsolidation.

\section{REFERENCES}

Bouma, A. H., 1969. Methods for the Study of Sedimentary Structures: New York (Wiley Interscience).

Bowles, J. E., 1970. Engineering Properties of Soils and Their Measurement: New York (McGraw-Hill).

Bredehoft, J. D., and Hanshaw, B. B., 1968. On the maintenance of anomalous fluid pressures: thick sedimentary sequences. Geol. Soc. Am. Bull., 81:1097-1106.

Bryant, W. R., Bennett, R. H., and Katherman, C. F., 1981. Shear strength, consolidation, porosity, and permeability of oceanic sediments. In Emiliani, C. (Ed.), The Sea: The Oceanic Lithosphere (Vol. 7): New York (John Wiley and Sons), pp. 1555-1615.

Carson, B., 1977. Tectonically induced deformation of deep-sea sediments off Washington and Northern Oregon: mechanical consolidation. Mar. Geol., 24:289-307. 
Carson, B., Yuan, J. W., Meyers, B. B., Jr., and Barnard, W. D., 1974. Initial deep-sea sediment deformation at the base of the Washington continental slope: a response to subduction. Geology, 2(11):561-564.

Casagrande, A., 1936. The determination of the pre-consolidation load. Proc. Int. Conf. Soil Mech. Found. Eng., 3:60-64.

Faas, R. W., 1982a. Plasticity characteristics of the Quaternary sediments of the Guatemalan continental slope, Middle America Trench, and Cocos Plate-Leg 67, Deep Sea Drilling Project. In Aubouin, J., von Huene, R., et al., Init. Repts. DSDP, 67: Washington (U.S. Govt. Printing Office), 639-644.

, 1982b. Gravitational compaction patterns determined from sediment cores recovered during the Deep Sea Drilling Project Leg 67 Guatemalan transect: continental slope, Middle America Trench, and Cocos Plate. In Aubouin, J., von Huene, R., et al., Init. Repts. DSDP, 67: Washington (U.S. Govt. Printing Office), 614-638.

Folk, R. L., 1974. Petrology of Sedimentary Rocks: Austin (Hemphill Publishing Co.).

Lambe, T. W., 1951. Soil Testing for Engineers: New York (John Wiley and Sons, Inc.).

Lambe, T. W., and Whitman, R. V., 1969. Soil Mechanics: New York (John Wiley and Sons, Inc.).

Lee, H. J., Olsen, H. W., and von Huene, R., 1973. Physical properties of deformed sediments from Site 181. In Kulm, L. D., von
Huene, R., et al., Init. Repts. DSDP, 18: Washington (U.S. Govt. Printing Office), 897-901.

Leg 87 Scientific Party, 1983. Leg 87 drills off Honshu and SW Japan. Geotimes, 28(1):15-18.

Lowe, J., Zaccheo, P. F., and Feldman, H. S., 1964. Consolidation testing with back pressure. J. Soil Mech. Found. Div. Am. Soc. Civ. Eng., 90:69-86.

Shephard, L. E., and Bryant, W. R., 1977. Consolidation characteristics of Japan Trench sediments. In Scientific Party, Init. Repts. $D S D P, 56,57$, Pt. 2: Washington (U.S. Govt. Printing Office), 1201-1205.

Skempton, A. W., 1970. The consolidation of clays by gravitational compaction. J. Geol. Soc., London, 125:373-411.

Taylor, E., and Bryant, W. R., in press. Geotechnical properties of sediments from the Middle America Trench and slope. In von Huene, R., Aubouin, J. et al., Init. Repts. DSDP, 84: Washington (U.S. Govt. Printing Office).

Trabant, P. K., Bryant, W. R., and Bouma, A. H., 1975. Consolidation characteristics of sediments from Leg 31 of the Deep Sea Drilling Project. In Karig, D. E., Ingle, J. C., Jr., et al., Init. Repts. DSDP, 31: Washington (U.S. Govt. Printing Office), 569-572.

Date of Initial Receipt: 11 May 1984

Date of Acceptance: 13 November 1984 
M. W. JOHNS
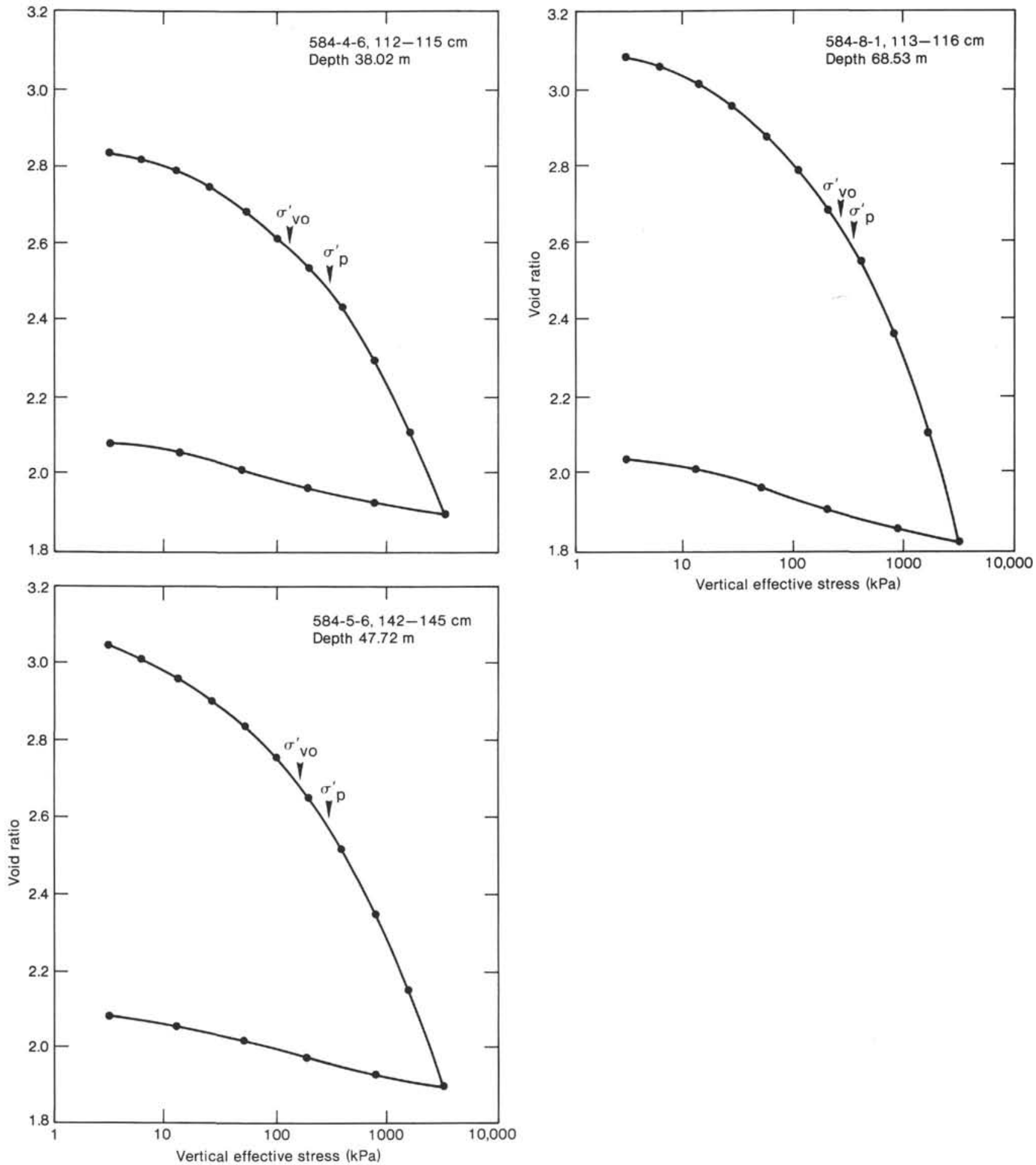

Figure 3. Site 584, void ratio versus logarithm of vertical effective stress (e versus $\log \sigma_{\mathrm{v}}^{\prime}$ ). Depths are sub-bottom depths. 


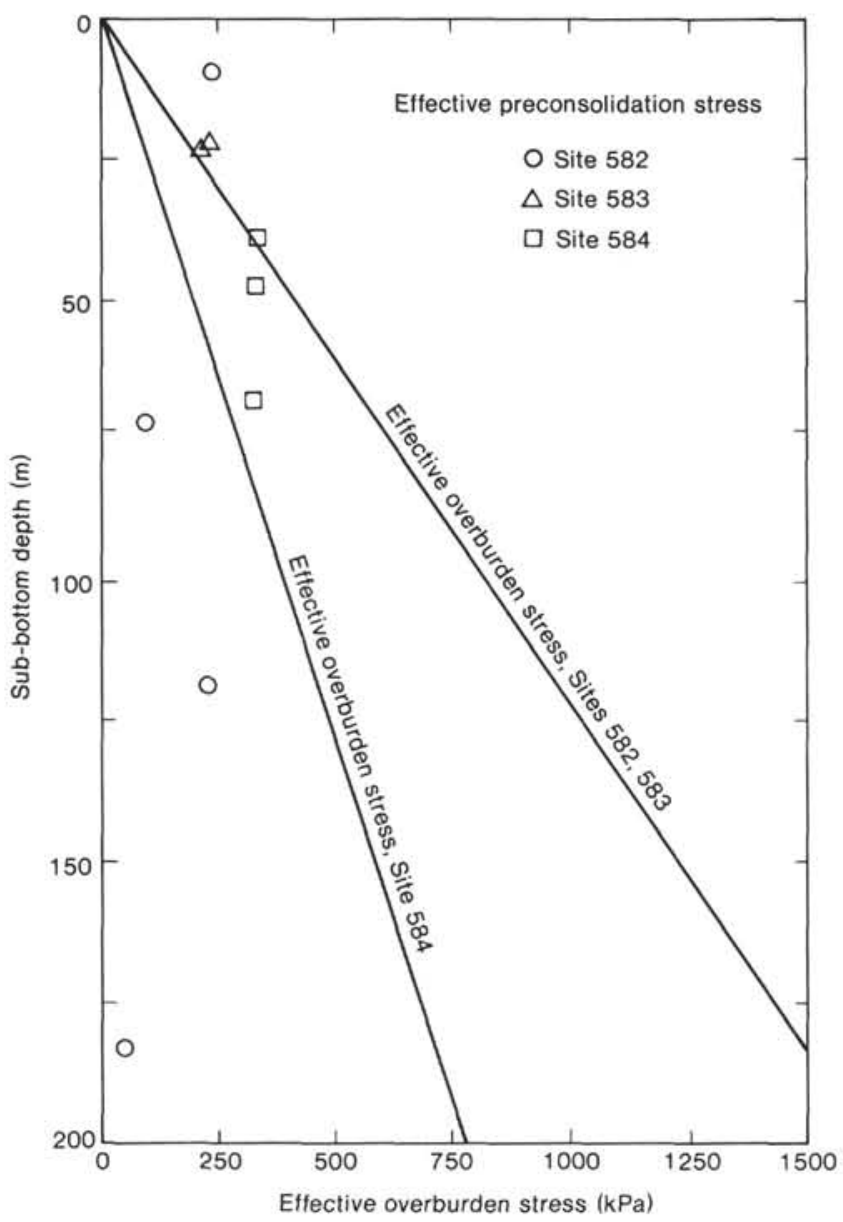

Figure 4. Depth versus effective overburden stress ( $\sigma_{v}^{\prime}$, solid lines) and effective preconsolidation stress ( $\sigma_{\mathrm{p}}^{\prime}$, individual symbols) for all samples tested.

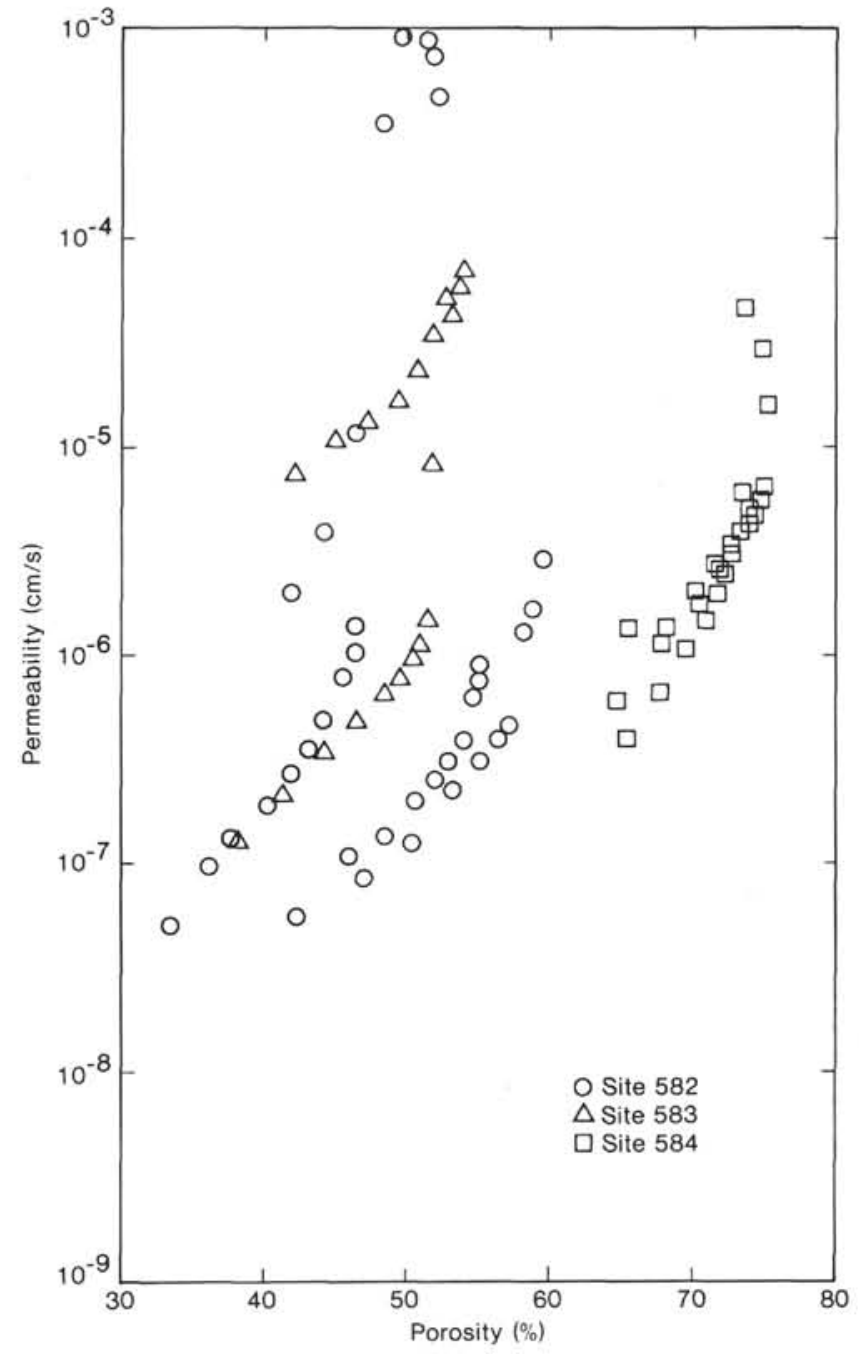

Figure 5. Coefficient of permeability versus porosity plot of all consolidation sample tests for Leg 87 sediments. 